\title{
POLITYKA MOCARSTW EUROPEJSKICH WOBEC TURCJI W LATACH 1903-1914
}

\author{
JAROSEAW RUBACHA
}

\begin{abstract}
Jarosław Rubacha, Polityka mocarstw europejskich wobec Turcji w latach 1903-1913 (The European powers policy towards Turkey in the years 1903-1914).

The years 1903-1914 should be considered as the most interesting period in the activity of the great power states in South-East Europe and Near East for a few reasons discussed below. In the final period of the formation of the antagonistic military-political alliances in Europe, the so called "Concert of Europe" mainly showed a great interest in maintaining the status quo and preventing any conflicts which could occupy their attention. These states also focused on Turkey and especially on its European dominion.
\end{abstract}

KEYWORDS: European Powers, Turkey, Balkan states, Macedonia, Albania

Balcanica Posnaniensia. Acta et studia, XXI, Poznań 2014, Wydawnictwo Instytutu Historii UAM, pp. 163-176, ISBN 978-83-63047-59-7, ISSN 0239-4278. Polish text with a summary in English.

Jarosław Rubacha, Uniwersytet Warmińsko-Mazurski w Olsztynie, Wydział Humanistyczny, Instytut Dziennikarstwa i Komunikacji Społecznej, ul. Kurta Obitza 1, 10-725 Olsztyn, j.rubacha@wp.pl.

Używając teatralnego porównania można stwierdzić, że Turcy wstapili jako aktorzy na europejską scenę polityczną niemal bezpośrednio po przybyciu na Stary Kontynent, czyli w połowie XIV w. Nie tylko udało im się w stosunkowo krótkim czasie zupełnie zmienić mapę polityczną Europy Południowo-Wschodniej i częściowo Środkowej, ale także stworzyć dobrze funkcjonujące i dysponujące potężną siłą militarną państwo, z którym liczyć musiały się największe potęgi europejskie. W miarę upływu czasu rola, jaką odgrywało Imperium Osmańskie, znacząco się jednak zmieniała, a ostatecznie już w połowie XIX stulecia zajęło ono miejsce wśród aktorów drugiego planu, czy wręcz statystów.

Taki stan rzeczy podyktowany był wieloma czynnikami. W pierwszym rzędzie należy zwrócić jednak uwagę na postępujący kryzys tureckiego systemu społecznogospodarczego, nazywanego spahijskim. Proces ten wpływał bezpośrednio na finanse państwa, a utrwalając patogenne zachowania korupcyjne osłabiał jego możliwości ekonomiczne i degradował aparat urzędniczy. Pośrednio wpływał on także na rozpad struktury wewnętrznej, potęgując separatystyczne dążenia lokalnych możnowładców oraz na stan sił zbrojnych, które pozbawione nowoczesnych środków prowadzenia walki, traciły dystans do innych armii państw europejskich. Na ten postępujący kryzys w XIX w. nałożył się jeszcze proces budzenia się świadomości narodowej zamiesz- 
kujących państwo tureckie ludów, który szczególnie mocno przebiegał w jego europejskich posiadłościach. Tym samym Turcja w szybkim tempie stawała się „kolosem na glinianych nogach”, coraz częściej nazywanym „chorym człowiekiem Europy”, a z jej słabości starały się korzystać wiodące państwa europejskie, które od połowy XIX w. zwykło się określać mianem wielkich mocarstw.

Warto podkreślić, że jakkolwiek zarówno poziom zainteresowania Turcją ze strony poszczególnych państw europejskich, jak i jego zakres na przestrzeni czasu ulegały zmianom, zawsze kierowały się one własnymi interesami i dążyły do realizacji partykularnych celów, rzadko uwzględniając interesy Wysokiej Porty. Tym samym, Turcja stała się przedmiotem gry politycznej wielkich mocarstw. Przyczyn takiego stanu rzeczy szukać należy przede wszystkim w procesie dynamicznej industrializacji Europy. Wiodące państwa Starego Kontynentu w tym czasie zaczęły wkraczać w tzw. erę imperialną, a jednym z naczelnych celów ich polityki zagranicznej stała się rozbudowa pozaeuropejskich posiadłości, które stanowić miały zaplecze surowcowe dla rozwijającego się przemysłu. Taki stan rzeczy bardzo szybko przekształcił się w zaciętą rywalizację o kolonie lub sfery wpływów, tym bardziej, że - zwłaszcza te ostatnie - lokowane były w tych częściach świata, które mogły stanowić równocześnie dogodny rynek zbytu dla europejskich towarów.

W wyścigu tym, aczkolwiek w różnych okresach, udział wzięły wszystkie wielkie mocarstwa, a Turcja i jej posiadłości stały się jednym z głównych jego elementów. Podyktowane to było tym, że państwo osmańskie, od kilku stuleci posiadające bliskie kontakty z Europa, prezentowało relatywnie wysoki poziom rozwoju cywilizacyjnego, a tym samym jawiło się jako dogodny rynek zbytu, tym bardziej, że od lat 30. XIX w. przechodziło skomplikowany proces reform, zwany erą tanzymatu, mający upodobnić je do innych krajów europejskich. Istotne znaczenie miał również fakt, że Turcja, dzięki swemu położeniu geograficznemu, kontrolowała ważne szlaki handlowe między Europą i Azją.

Równie istotną kwestią była sprawa prestiżu na arenie międzynarodowej i rywalizacja o swego rodzaju „palmę pierwszeństwa” - pozycję hegemona w wymiarze tak europejskim, jak i ogólnoświatowym, która ściśle wiązała się ze wspomnianą powyżej kwestią ekonomiczną. Zdobycie uprzywilejowanej pozycji wymagało, bowiem, umiejętnego blokowania inicjatyw konkurentów, a to można było osiagnąć jedynie działaniami natury politycznej. W tym aspekcie Turcja i jej rozległe terytorium położone w Europie, Azji i Afryce oraz sprawowana przez nią kontrola nad strategicznym szlakiem komunikacyjnym z Morza Czarnego na Morze Śródziemne przez Bosfor i Dardanele, zwracała szczególną uwagę mocarstw, a działania na rzecz zdobycia przewagi w tym regionie ograniczały się generalnie do dwóch obszarów. Pierwszym z nich były podejmowane przez Wielką Brytanię i Francję próby utrzymania integralności terytorialnej Turcji przy jednoczesnym wzmocnieniu własnych wpływów - głównie ekonomicznych - w tym państwie. Takie działania nie tylko dawały możliwość czerpania znacznych zysków z wymiany handlowej z Imperium Osmańskim, ale także, poprzez utrwalenie tam własnych wpływów, blokowania inicjatyw konkurentów w innych newralgicznych rejonach świata, np. rosyjskich prób poszerze- 
nia stanu posiadania na Zakaukaziu, w Azji Centralnej i na Dalekim Wschodzie ${ }^{1}$. W drugim obszarze lokowały swoje działania mocarstwa o mniejszym potencjale ekonomicznym, niemogące bezpośrednio konkurować z gospodarkami brytyjską czy francuską, czyli Rosja i Austro-Węgry, a później także Włochy. Dostrzegały one natomiast możliwość realizacji swoich celów w pozbawianiu państwa osmańskiego kolejnych prowincji. Stąd też krzyżowanie się interesów mocarstw doprowadziło ostatecznie do wybuchu tzw. kryzysu wschodniego, który - mimo podejmowanych wielokrotnie prób jego zażegnania - przetrwał praktycznie aż do wybuchu I wojny światowej.

Dziesięcioletni okres, zawierający się pomiędzy rokiem 1903 a 1913-1914, uznać należy za jeden z najciekawszych etapów działań wielkich mocarstw wobec Turcji Osmańskiej, skupiający w sobie kilkadziesiąt lat ich wcześniejszy działań w tym obszarze. Okres ten podzielić można na cztery podstawowe fazy.

Pierwsza z nich, obejmująca lata 1903-1908, charakteryzuje się pełnym i zgodnym działaniem mocarstw, co podyktowane było przede wszystkim chęcią zabezpieczenia pokoju na Bałkanach, ale także próbami zabezpieczenia integralności tureckiego terytorium i wzmocnienia własnych wpływów w tym kraju.

Latem 1903 r. w bałkańskich posiadłościach Turcji, a konkretnie w Macedonii, rozegrały się dramatyczne wydarzenia, nazywane w historiografii powstaniem ilindeńsko-preobrażeńskim. Poruszone okrucieństwami Turków dokonujących pacyfikacji Macedonii, a przede wszystkim obawiające się włączenia się w konflikt państw bałkańskich Rosja i Austro-Węgry, wspierane przez pozostałe mocarstwa, pod koniec 1903 r. wymogły w Konstantynopolu przyjęcie programu reform, którego podstawy określone zostały w trakcie rozmów przeprowadzonych w Petersburgu w 1897 r. Przewidywał on wyznaczenie nowego gubernatora, mianowanie przy tureckich inspektorach wilajetów komisarzy rosyjskiego i austro-węgierskiego, którzy czuwaliby nad bezpieczeństwem ludności chrześcijańskiej, reformę żandarmerii w wilajetach: kosowskim, monastirskim i salonickim pod nadzorem zagranicznej kadry oficerskiej, podział Macedonii na okręgi według granic etnicznych, a także wiele zmian w administracji i sądownictwie, które zapewnić miały dostęp urzędników chrześcijańskich do tych struktur ${ }^{2}$. Tempo zmian, głównie z powodu oporu władz tureckich, było jednak bardzo wolne, co spowodowało aktywne włączenie się w akcję reform także pozostałych mocarstw. Wynikiem wspólnych działań Macedonia została podzielona na sektory, którymi zarządzali, oprócz urzędników tureckich, oficerowie delegowani przez mocarstwa. Austro-Węgry objęły wilajet kosowski, Włochy - monastirski,

\footnotetext{
${ }^{1}$ A. Malinowski, Europejskie posiadłości Turcji w polityce Wielkiej Brytanii (1903-1914), Słupsk 2014, s. 25.

${ }^{2}$ B. Koskowski, Turcya w Europie, „Biblioteka Warszawska”, 1908, t. 4, s. 229-230, H. Batowski, Państwa bałkańskie 1800-1923. Zarys historii dyplomatycznej i rozwoju terytorialnego, Kraków 1938, s. 147, A. Giza, Państwa batkańskie wobec kwestii macedońskiej w latach 1878-1918, Szczecin 1998, s. 81-85; na ten temat także: N. Forbes, A. J. Toynboe, D. Mitrany, D. G. Hogarth, The Balkans. A History of Bulgaria, Serbia, Greece, Rumania, Turkey, Oxford 1915, s. 69, H. W. Steed, The Hapsburg Monarchy, London 1919, s. 228.
} 
a wilajet salonicki podzielony został między pozostałe państwa: sandżak salonicki objęła Rosja, sereski - Francja, a dramański - Wielka Brytania. Reorganizację żandarmerii powierzono generałowi włoskiemu, którego wspierać miała grupa sześćdziesięciu oficerów pochodzących z różnych państw europejskich. Jednocześnie dodano przedstawicieli pozostałych mocarstw do już rezydujących przy inspektorach wilajetów komisarzy rosyjskiego i austriackiego. Zdecydowanie gorzej wyglądała kwestia zmian w innych obszarach. Decyzję mocarstw o poddaniu międzynarodowej kontroli finansów publicznych w Macedonii i dofinansowaniu reform w tej prowincji przez Turcję, Wysoka Porta odrzuciła, motywując to tym, że określone przez mocarstwa kwoty są zbyt wysokie, a nadzór międzynarodowej komisji nad finansami jest ingerencją w jej sprawy wewnętrzne i pogwałceniem jej suwerenności, jakkolwiek równocześnie podkreśliła, że kwestia reformy finansów w prowincji są ważne i prowadzone będą przez bank narodowy. Dopiero kolektywna nota wielkich mocarstw, w której zagroziły one władzom tureckim poważnymi sankcjami ekonomicznymi, ostatecznie przełamała opór Wysokiej Porty i spowodowała zwiększenie finansowania reform w Macedonii. Równie wolno przebiegały zmiany w sądownictwie i administracji. Poza tym działania mocarstw oceniano krytycznie w Konstantynopolu i interpretowano, jako mieszanie się sił postronnych w wewnętrzne sprawy państwa tureckiego. Takie przeświadczenie rodziło opór części środowisk politycznych i ostatecznie doprowadziło to w 1908 r. do wybuchu rewolucji młodotureckiej i przekształcenia Turcji w kraj konstytucyjny.

Składane przez nowe władze zapewnienia, że odtąd prawa wszystkich obywateli będą szanowane, skłoniły wielkie mocarstwa do porzucenia akcji reformatorskiej, a jednocześnie powrotu do rywalizacji o sfery wpływów i działań na rzecz realizacji partykularnych interesów. Chaos, jaki zapanował w Turcji po zmianie władzy, a jednocześnie rosnące potrzeby finansowe rządu młodotureckiego, zabiegającego o pozyskanie środków na realizację własnych planów, stwarzał, bowiem, możliwości nowego ułożenia stosunków gospodarczych i politycznych oraz zmiany stosunku sił w tym obszarze, ukształtowanego jeszcze pod koniec XIX w. Na działaniach tych zaważyły jednak w dużej mierze niejednolite oceny wydarzeń, które rozegrały się w Turcji. Mocarstwa Trójporozumienia odniosły się do nich ogólnie negatywnie Rosja wręcz wrogo, Wielka Brytania - z lekceważeniem i pogardą, a Francja - będąca największym wierzycielem Turcji i posiadająca kontrolę nad tureckim długiem publicznym - z obojętnością. Tym samym zaprzepaściły one szansę na wzmocnienie swoich wpływów nad Bosforem, a podejmowane w okresie późniejszym próby zmiany tej sytuacji, z góry skazane były na niepowodzenie.

Więcej uwagi zmianie sytuacji w państwie osmańskim poświęcili Niemcy, którzy po odrzuceniu przez Francję prośby rządu tureckiego o pożyczkę w 1910 r., udzieliły mu kredytu na preferencyjnych warunkach, co niewątpliwie zbliżyło Turcję do Cesarstwa Niemiec i utrwaliło pozycję kapitału niemieckiego w tym kraju, potwierdzoną już wcześniej monopolem na dostawy sprzętu wojskowego i broni z 1883 r., kontraktami na modernizację armii z 1885 i 1908 r. oraz licznymi koncesjami na budowy linii kolejowych i wydobycie surowców. Stworzonych i umocnionych podstaw 
dobrych stosunków niemiecko-tureckich nie były w stanie naruszyć nawet działania podjęte przez inne mocarstwa Trójprzymierza.

Zwycięstwo rewolucji młodotureckiej zapoczątkowało nowy, aczkolwiek krótkotrwały okres w stosunkach między mocarstwami europejskimi a Turcją którego ramy wyznaczyć można na lata 1908-1909. Charakteryzował się on powrotem do koncepcji podziału tureckiego terytorium, zgodnie z własnymi interesami. Głoszone przez komitet „Jedność i Postęp” hasła odnowy świetności państwa osmańskiego, z dużymi obawami zostały przyjęte przez Austro-Węgry, gdzie szybko uświadomiono sobie, że zachodzące w Turcji zmiany mogą poważnie utrudnić realizację głównego celu habsburskiej polityki zagranicznej, którym niezmiennie od połowy XIX w. było zapewnienie sobie wygodnego i bezpiecznego szlaku handlowego do portu w Salonikach. Stąd też informacje napływające $\mathrm{z}$ Konstantynopola, mobilizowały rząd austro-węgierski do jak najszybszego rozwiązania kwestii przynależności Bośni i Hercegowiny, która od 1878 r. znajdowała się pod administracją austriacką. Działania te zdecydowano się ostatecznie podjąć nawet bez uzyskania formalnej zgody innych mocarstw, a zwłaszcza największego konkurenta na Bałkanach - Rosji. Sprawa stawała się tym pilniejsza, że z Konstantynopola, formalnego zwierzchnika Bośni i Hercegowiny, zaczęły dochodzić głosy wzywające przedstawicieli tej prowincji do zajęcia należnego im miejsca w parlamencie tureckim. Wezwania te spotykały się z żywym odzewem $^{3}$, a miejscowa ludność muzułmańska coraz częściej bojkotowała zarządzenia administracji austriackiej ${ }^{4}$. Wysuwane równocześnie hasła zapowiadające rewindykację utraconych terytoriów, stwarzały zagrożenie, że Turcja zażąda ich zwrotu ${ }^{5}$, powołując się na protokół kongresu berlińskiego z 13.07.1878 r., który przewidywał między innymi, że okupacja Bośni i Hercegowiny będzie miała charakter czasowy ${ }^{6}$. Tymczasem powrót tej prowincji pod panowanie tureckie, poza stratami finansowy$\mathrm{mi}^{7}$, stawiałby monarchię habsburską w niekorzystnej sytuacji w wymiarze zarówno międzynarodowym, jak i wewnętrznym. Stąd też, nie czekając na dalszy rozwój wypadków w Europie i w Turcji, na początku października 1908 r., inkorporowano Bośnię i Hercegowinę do monarchii habsburskiej. Fakt ten wywołał poważny kryzys polityczny nazywany bośniackim, który omal nie zakończył się wybuchem wojny rosyjsko-austriackiej. Tylko stanowcza postawa Niemiec sprawiła, że Rosja, pozbawiona wsparcia swoich sojuszników, zrezygnowała z konfrontacji. Równocześnie dyplomaci austro-wegierscy starali się jak najszybciej uzyskać porozumienie z Turcją, która

\footnotetext{
${ }^{3}$ Z. Stefański, Przesilenie bałkańskie, „Świat Słowiański”, 1909, t. 1, s. 28.

${ }^{4}$ Die große Polityk der europäischen Kabinette, 1871-1914; Sammlung der diplomatischen Akten des Auswärtigen Amtes, hrsg. J. Lepsius, A. Mendelssohn-Bartholdy, F. Thimme (cyt. dalej DGP), t. 26, Berlin 1922, nr 8978.

${ }^{5}$ Z. Stefański, Przesilenie bałkańskie, „Świat Słowiański”, 1909, t. 1, s. 28, G. Roloff, Die Entstehung des Balkanbundes von 1912. Akademische Rede zur Jahresfeier der Hess. Ludvigs-Universität am 1. Juli 1922, Geissen 1922, s. 6; na ten temat także: H. Batowski, Państwa..., s. 162.

${ }^{6}$ T. von Sosnosky, Die Balkanpolitik Österreich-Ungarns seit 1866, t. 2, Berlin 1914, s. 186.

${ }^{7}$ Z. Stefański, Stosunki agrarne w Bośni i Hercegowinie, „Świat Słowiański”, 1905, t. 1, s. 285-294 oraz idem, W sprawie agrarnej w Bośni i Hercegowinie, ibidem, s. 385-387.
} 
zdecydowanie zaprotestowała przeciw aneksji, jakkolwiek w Konstantynopolu zdawano sobie sprawę z faktu, że - przy generalnie biernej postawie innych mocarstw szanse przywrócenia status quo ante nie będą możliwe. Stąd też rząd turecki, godząc się ostatecznie na aneksję Bośni i Hercegowiny, zamierzał uzyskać w zamian jak największe korzyści. Pertraktacje zakończyło podpisanie 26. 02. 1909 r. w Stambule traktatu, na mocy którego Austro-Węgry rezygnowały z prawa do okupacji Sandżaku Nowopazarskiego, a Turcja zaakceptowała nowy stan prawny Bośni i Hercegowiny. Jednocześnie monarchia habsburska gwarantowała mahometanom wolność wyznania i akceptowała zwierzchność religijną sułtana, jako kalifa, ponadto wszystkim opuszczającym terytorium bośniackie zagwarantowano zachowanie prawa do nieruchomości i administrowania nimi z terytorium tureckiego. Za pozostający na terenie Bośni i Hercegowiny majątek państwowy Austro-Węgry zobowiązywały się zapłacić rządowi tureckiemu odszkodowanie w wysokości 2,5 mln. funtów tureckich. Poza tym dokument zawierał wiele ustępstw natury gospodarczej i postanowień wzmacniających prestiż Wysokiej Porty na arenie międzynarodowej ${ }^{9}$. Warto jednak dodać, że aneksja jednej z tureckich prowincji przez członka „koncertu europejskiego”, naruszając ducha traktatu berlińskiego, otwarła drogę państwom bałkańskim do szukania możliwości realizacji własnych planów kosztem Turcji.

W kontekście działań prowadzonych przez mocarstwa wobec Turcji, a mających na celu pozbawienie jej części terytorium, wspomnieć także należy o wysiłkach Włoch, które w tym okresie przystępowały do realizacji idei wzmocnienia swojej pozycji w basenie Morza Śródziemnego. Mimo że działania te Włosi prowadzili za wiedzą i zgodą Ententy, a na skutek nieoficjalnych działań dyplomatycznych uwieńczonych tajnymi porozumieniami z Trójporozumieniem z lat 1900, 1902 i 1909 de facto tylko nominalnie współtworzyli „blok niemiecki”, wybuch wojny włosko-tureckiej mógł znacząco zachwiać wpływami Berlina w Turcji. Potwierdzać mógł to fakt, że o pomoc rząd turecki zwrócił się nie do Niemiec, ale do Ententy. Wielka Brytania nie zdecydowała się jednak na żadne kroki, a Rosja wystąpiła jedynie z propozycją mediacji w celu jak najszybszego zakończenia konfliktu. Propozycji tej towarzyszyły próby wskrzeszenia pomysłu stworzenia sojuszu bałkańskiego z udziałem Turcji. Idea ta pojawiła się po raz pierwszy latem 1909 r., a próby wdrożenia jej w życie podjął ówczesny ambasador rosyjski w Konstantynopolu Mikołaj Czarykow.

W tym momencie otwarł się także nowy, trzeci już etap w stosunkach między wielkimi mocarstwami a Turcją, obejmujący okres od 1909 do 1912 r., w którym główny ciężar prowadzonych działań kładziony był na próby pozyskania Wysokiej Porty do ewentualnej współpracy polityczno-militarnej. Działania te prowadziła

${ }^{8}$ Österreich-Ungarns Aussenpolitik von bosnischen Krise 1908 bis zum Kriegsausbruch 1914. Diplomatische Aktenstücke des Österreich-Ungarischen Aussenministeriums, ausg. von L. Bittner, A. F. Pribram, H. Srbik und H. Übersberger, (cyt. dalej: ÖUA), t. 2, Wien / Berlin 1930, nr 1313. Umowa została ratyfikowana 15.40.1908 r.; ibidem, nr 1522. Równocześnie Austro-Węgry formalnie zrzekały się zagwarantowanego w traktacie berlińskim prawa do okupacji sandżaku Novi Pazar, co ogłoszono wraz z aktem aneksji Bośni i Hercegowiny. Austriackie garnizony zostały ewakuowane z sandżaku już 28.10.1908 r.

${ }^{9}$ ÖUA, t. 1, nr 1061 i n. 
w zasadzie wyłącznie Rosja, ale początkowo cieszyły się one poparciem jej partnerów z Ententy - Wielkiej Brytanii ${ }^{10}$ i Francji ${ }^{11}$. Próby przyciagnięcia Turcji do trójprzymierza dyplomacja rosyjska podjęła kierując się dwoma kluczowymi czynnikami. Po pierwsze taki alians mógł wyeliminować niebezpieczeństwo wybuchu wojny na Bałkanach, a po drugie zapewnić rosyjskiej flocie wojennej i handlowej swobodę żeglugi w Cieśninach Czarnomorskich. Ta druga kwestia była dla rządu rosyjskiego szczególnie ważna. Zakrojone na szeroką skalę działania dyplomatyczne w tym obszarze, a także wielokrotnie podejmowane próby nacisku zbrojnego na Turcję już od I połowy XIX w., nie dawały bowiem spodziewanych rezultatów. Tymczasem fakt zamknięcia cieśnin dla okrętów rosyjskiej marynarki wojennej boleśnie odczuła Rosja w 1905 r., kiedy flota czarnomorska nie mogła wziąć udziału w wojnie z Japonią. Fakt ten utwierdził Rosjan w przekonaniu, że istniejący status Bosforu i Dardaneli nie tylko nie odpowiada ich potrzebom, ale jest dla nich wręcz szkodliwy. Poza względami politycznymi istotną rolę odgrywały tu także przyczyny ekonomiczne. Ocenia się, że w pierwszym dziesięcioleciu XX w., średnio 37\% rosyjskiego eksportu kierowano przez Bosfor i Dardanele, a przed wybuchem I wojny światowej 60-70\% wywożonego zboża opuszczało Rosję właśnie przez Cieśniny Czarnomorskie ${ }^{12}$.

Stąd też Czarykow podjął bardzo energiczne działania ${ }^{13}$, na rzecz realizacji planu, który zakładał stworzenie sojuszu opartego na szerokich i solidnych podstawach politycznych i ekonomicznych, który początkowo skupiać miał Serbię, Bułgarię, Czarnogórę i Turcję, a następnie poszerzony miał zostać o Grecję i Rumunię. Jednocześnie Rosja zachować w nim miała duże wpływy, które gwarantowałyby jej pełną kontrolę nad podejmowanymi przez sojuszników działaniami. Wpływy te utrwalone miały zostać przede wszystkim poprzez udzielaną przez Petersburg pomoc finansową.

Do budowy zakładanego przez Czarykowa sojuszu konieczna jednak była likwidacja napięć i niesnasek panujących między mającymi go tworzyć państwami. Pierwszoplanową kwestią do rozwiązania, jaka stawała przed dyplomacją rosyjską, było zbliżenie między Serbią i Bułgarią, przy czym Czarykow przewidywał możliwość nie tylko nawiązania przyjacielskich stosunków między oboma państwami, ale także wyrzeczenie się przez nie aspiracji do europejskich prowincji tureckich Macedonii i Sandżaku Nowopazarskiego ${ }^{14}$. Te ambitne plany znalazły jednak uznanie wyłącznie w oczach potrzebujących sukcesów dyplomatycznych „młodoturków”.

10 DGP, t. 27, nr 9744.

11 DGP, t. 27, nr 9751, 9795, ÖUA, t. 2, nr 2097.

12 M. Tanty, Rosja wobec wojen batkańskich 1912-13, Warszawa 1970, s. 39, tab. nr 1, H. Batowski, Cieśniny Tureckie 1911-1936, Warszawa 1936, s. 5-6. W 1910 r. wartość wywozu rosyjskich produktów przez Cieśniny Czarnomorskie wyniosła 627.000.000 rubli, co stanowiło 43,3\% ogólnej wartości eksportu tego państwa; por. Mieždunarodnije otnošenija $w$ epochu imperijalizma. Dokumienti iz archivov carskogo i vriemiennogo pravitielstv 1878-1917, s. II 1900-1913, Moskwa-Leningrad 1940, t. 21, cz. 1, nr 374.

13 ÖUA, t. 2, nr 1839, 1890, t. 3, nr 2951.

14 Zob. ÖUA, t. 2, nr 1923. 
Pozostali politycy tureccy odnosili się do rosyjskich koncepcji bardzo sceptycznie, nie wierząc, że uda się doprowadzić do ujednolicenia stanowisk nie tylko na linii Wysoka Porta - państwa bałkańskie, ale nawet między samymi państwami Półwyspu oraz obawiając się, iż w przyszłości Rosja faworyzować będzie innych członków sojuszu kosztem Turcji ${ }^{15}$. Równocześnie w tureckich kręgach politycznych zaczęto sprzeciwiać się koncepcjom skierowania ewentualnego sojuszu przeciw państwom centralnym, a nawet domagano się zbliżenia do nich ${ }^{16}$. Podobnie sceptycznie odniosły się do zabiegów Czarykowa państwa bałkańskie. Dlatego też mimo wysiłków rosyjskiego dyplomaty plan ten nigdy nie wszedł $\mathrm{w}$ fazę realizacji, ale do jego założeń powrócono w 1911 r., niedwuznacznie sugerując rządowi tureckiemu, że w przypadku przeciągającej się wojny z Włochami Turcji grożą poważne komplikacje na Bałkanach. Turcja jednak konsekwentnie odrzucała rosyjskie propozycje zarówno w obszarze mediacji, jak i ewentualnego włączenia się w prace nad tworzeniem bloku bałkańskiego.

Okres bezpośrednio poprzedzający wybuch wojen bałkańskich i pierwszy etap konfrontacji, to bodaj ostatni przykład próby kolektywnych działań wielkich mocarstw wobec Turcji, a zarazem czwarta faza, którą wyodrębnić można w kontaktach pomiędzy nimi a Wysoką Porta. Warto jednak podkreślić, że w związku z rozwojem sytuacji na Bałkanach, ta postawa ulegała stopniowej zmianie, by ostatecznie kwestia turecka przestała odgrywać istotniejszą rolę w polityce europejskiej.

Wspólne działania na rzecz ratowania pokoju i status $q u o^{17} \mathrm{w}$ Europie PołudniowoWschodniej mocarstwa podjęły dopiero w połowie sierpnia $1912 \mathrm{r}$. Wynikało to przede wszystkim z faktu, że okoliczności powstania i rzeczywiste cele sojuszu bałkańskiego utrzymywane były w tajemnicy lub nie były traktowane poważnie. Stąd też próby rozładowania napiętej sytuacji na Bałkanach ${ }^{18}$ rozpoczęły się 13.08 .1912 r. od austrowęgierskiego memorandum, w którym zaproponowano innym mocarstwom wspólny nacisk na Turcję w kwestii wprowadzenia reform w Albanii i Macedonii. W wszelkie kwestie z tym związane przedstawiciele „koncertu europejskiego” omówić mieli podczas zwołanej specjalnie w tym celu konferencji ${ }^{19}$. Plan ten spotkał się z życzliwym przyjęciem w Wielkiej Brytanii ${ }^{20}$, która dodatkowo zaproponowała przedsięwzięcie stanowczych kroków w Konstantynopolu na rzecz zagwarantowania praw pozostałym narodom chrześcijańskim zamieszkującym europejskie posiadłości Turcji oraz Francji, która przewidywała nawet udzielenie Rosji i Austro-Węgrom specjalnego

${ }^{15}$ Skrajni pesymiści twierdzili nawet, iż przygotowywany przez Czarykowa sojusz skieruje się ostatecznie przeciw Turcji i doprowadzi do jej rozbioru; O. Bickel, Russland und die Entstehung des Balkanbundes 1912. Ein Beitrag zur Vorgrschichte des Weltkrieges. Dargestellt vorwiegend auf Grund des amtlichen Aktenmaterials, Königsberg / Berlin 1933, s. 75.

16 ÖUA, t. 2, nr 1918, DGP, t. 26, nr 9737, 9739, 9743, 9744.

${ }^{17}$ B. von Siebert, Diplomatische Aktenstücke..., s. 533-534.

18 ÖUA, t. 4, nr 3687, 3712, 3714, M. Semow, op. cit., s. 78, B. von Siebert, Diplomatische Aktenstücke zur Geschichte der Ententepolitik der Vorkriegsjahre, Berlin 1921, s. 533-534.

${ }^{19}$ B. von Siebert, op. cit, s. 537.

${ }^{20}$ Ibidem, s. 538, 553, British Documents on the Orgins of the War 1898-1914, (cyt. dalej: BD), London 1926, t. 9, nr 715. 
mandatu europejskiego, który dałby im możliwość wspólnego działania na rzecz ograniczenia niepokojów na Bałkanach oraz zachowania status quo ${ }^{21}$. Stanowisko to poparte zostało także przez Rosję ${ }^{22}$. Wkrótce jednak pojawiły się zastrzeżenia odnośnie realności wprowadzenia tej idei w życie, co w znaczący sposób zaważyło na tempie prac. Wattpliwości, co do możliwości wprowadzenia w życie planu austro-węgierskiego ${ }^{23}$, nie oznaczały całkowitego porzucenia przez wielkie mocarstwa prób zażegnania wybuchu konfliktu na Bałkanach. Na początku września 1912 r. ster akcji dyplomatycznej objęła Francja ${ }^{24}$, a gorącym orędownikiem wspólnej akcji mocarstw w Konstantynopolu i stolicach państw bałkańskich stał się rząd rosyjski ${ }^{25}$. Jakkolwiek jednak zarówno w Londynie, jak i w Berlinie plany rosyjsko-francuskie przyjmowano $\mathrm{z}$ dużym zainteresowaniem ${ }^{26}$, ani Niemcy, ani Wielka Brytania nie zadeklarowały otwarcie chęci aktywnego włączenia się w próby zażegnania konfliktu na Bałkanach $^{27}$. W związku z tym dyplomacja rosyjska podjęła decyzję o samodzielnym działaniu. W dniu 17.09.1912 roku $^{28}$ przekazano Turcji projekt daleko idących reform w Macedonii ${ }^{29}$, dzięki którym ludność chrześcijańska w jej europejskich posiadłościach uzyskać miała m.in. gwarancje bezpieczeństwa osób i mienia, równość wobec prawa oraz udział w administracji lokalnej, odpowiadający etnicznemu składowi tejże ludności w poszczególnych częściach państwa tureckiego ${ }^{30}$. Idea ta nie zyskała jednak pełnej aprobaty innych wielkich mocarstw, co spowodowało przeciagganie się dyskusji, a ich ostatecznym efektem była nota do państw bałkańskich, wzywająca je do zachowania spokoju oraz deklaracja, że „koncert europejski” nie dopuści do jakichkolwiek zmian terytorialnych na Bałkanach, przekazana 8.10.1912 ${ }^{31}$. W dwa dni później przesłano również notę do Turcji, w której mocarstwa wzywały ją do przeprowadzenia reform zgodnie z postanowieniami traktatu berlińskiego ${ }^{32}$. Jednak w związku $\mathrm{z}$ napięciem, jakie panowało w tym czasie w stosunkach między Wysoką Portą a sojusznikami bałkańskimi, wezwania te pozostały jedynie pustą literą.

${ }^{21}$ B. von Siebert, op. cit., s. 535, 551-552.

22 DGP, t. 33, nr 12104.

${ }^{23}$ B. von Siebert, op. cit., s. 546-550, Der diplomatische Schriftwechsel Iswolskis 1911-1914, hrsg. F. Stieve, Berlin 1926, t. 2, nr 508. BD, t. 9, nr 658, 659, DGP, t. 33, nr 12091, 12093, 12119 ÖUA, t. 4, nr 3731, 3766.

${ }^{24}$ Austro-Hungarian Monarchy. Ministerium des K. und K. Hauses und des Äussern, Diplomatische aktenstücke betreffend die ereignisse am Balkan von 13. August 1912 bis 6. Noveber 1913, Wien 1914, s. 537, Der diplomatische Schriftwechsel..., t. 2, nr 439.

${ }^{25}$ R. Poincaré, Geneza wojny światowej. Sześć odczytów w Paryżu w 1921 r., Kraków 1921, s. 72.

${ }^{26}$ Ibidem, s. 73, B. von Siebert, op. cit., s. 538.

${ }^{27}$ B. von Siebert, op. cit., s. 536, 546-550, ÖUA, t. 4, nr 3718, DGP, t. 33, nr 12126.

${ }^{28}$ R. Poincaré, op. cit., s. 73.

${ }^{29}$ Mieždunarodnije otnošenija.., t. 20, cz. 2, nr 541, BD, t. 9, nr 674, 718, 732, ÖUA, t. 4, nr 3809.

${ }^{30}$ R. Poincaré, op. cit., s. 73, Der diplomatische Schriftwechsel..., nr 402.

31 ÖUA, t. 4, nr 4009, 4010, 4018, 4019, 4020, A. Krzyżanowski, Wojna batkańska w roku 1912/13. Odbitka z „Przegladu Powszechnego”, Kraków 1913, s. 82, H. Batowski, Państwa..., s. 188, T. von Sosnosky, op. cit., s. 279, W. Schröder, England, Europa und der Orient, Stuttgart 1938, s. 144-145.

32 ÖUA, t. 4, nr 4024, 40254026. 
Jednak pasmo klęsk ponoszonych przez Turcję w trakcie I wojny bałkańskiej skłoniło wielkie mocarstwa do działania. Jakkolwiek bez entuzjazmu zareagowały one na skierowaną na ich ręce na początku listopada 1912 r. prośbę o mediację w rozmowach pokojowych ${ }^{33}$, nie zamierzały biernie przyglądać się rozwojowi sytuacji. Szczególne zaniepokojenie budziła możliwość ewentualnego wkroczenia armii bułgarskiej do Konstantynopola ${ }^{34}$. Zajęcie tureckiej stolicy przez Bułgarów stworzyłoby, bowiem, zupełnie nową sytuację polityczną w okolicach cieśnin czarnomorskich. Dlatego też, aby zapobiec niekontrolowanemu rozwojowi wypadków, już na przełomie października i listopada 1912 r. mocarstwa skierowały w okolice Bosforu, Dardaneli oraz na Morze Śródziemne eskadry swoich okrętów wojennych. Równocześnie obawy, które wywołane zostały przebiegiem wydarzeń na Bałkanach, postanowiła wykorzystać Turcja. Już 3.11.1912 r. zezwoliła okrętom państw - sygnatariuszy traktatu berlińskiego na wejście do Dardaneli ${ }^{35}$, licząc, że obecność flot wielkich mocarstw z jednej strony powstrzyma Bułgarów przed podjęciem prób opanowania Konstantynopola, a z drugiej strony uchroni stolicę przed skutkami ewentualnego buntu zdemoralizowanych jednostek tureckich, zgromadzonych w okolicach Stambułu. W związku z tym między 5. a 19.11.1912 r. do Konstantynopola przybyło łącznie 17 okrętów wojennych reprezentujących wielkie mocarstwa oraz Hiszpanię, Holandię i Rumunię ${ }^{36}$. $\mathrm{Z}$ ich załóg utworzony został, liczący ponad 2.500 marynarzy międzynarodowy korpus pod dowództwem francuskiego kontradmirała Louisa Dartige du Fourneta, który zajął strategiczne punkty w mieście. Korpus ten stanowić miał siły rozjemcze na wypadek wejścia armii bułgarskiej do Konstantynopola ${ }^{37}$. Równocześnie jednak mocarstwa porzuciły lansowaną wcześniej ideę nienaruszalności istniejącego na Bałkanach status quo, podkreślając jednocześnie, że warunkiem podziału europejskich posiadłości Turcji jest natychmiastowe wstrzymanie operacji wojennych ${ }^{38}$.

Ulegając tym sugestiom sojusznicy bałkańscy zgodzili się na rozpoczęcie negocjacji pokojowych. Jako miejsce obrad wyznaczono Londyn, a wielkie mocarstwa, jakkolwiek oficjalnie nie uczestniczyły w obradach, starały się wpływać na tok rozmów tak, aby podejmowane decyzje nie stały w sprzeczności z ich interesami. W tym celu również w Londynie otwarła swoje obrady konferencja ambasadorów. Warto także podkreślić, że wspomniana zmiana stanowiska mocarstw odnośnie status quo na Bałknach w znaczący sposób zaważyła na przebiegu dyskusji. Potwierdziły to już

33 ÖUA, t. 4, nr 4251, 4265, 4268, 2496 i n., Der diplomatische Schriftwechsel..., t. 2, nr 546, Mieždunarodnije otnošenija..., t. 21, cz. 1, nr 146, 170, M. Semow, op. cit., s. 106

34 ÖUA, t. 4, nr 3879, 4165, B. von Siebert, op., cit., s. 558-559, 563, B. von Siebert, op., cit., s. $565-$ -567, Der diplomatische Schriftwechsel..., t. 2, nr 547, A. Giza, Armia bułgarska $w$ dobie wojen batkańskich 1912-1913; w: „Studia i Materiały do Historii Wojskowości”, 1998, t. 39, s. 141, DGP, t. 33, nr 12364, t. 34, cz. 1, nr 12761, M Tanty, Rosja..., s. 95-95, 98-99 i n., Mieždunarodnije otnošenija ..., t. 21, cz. 1, nr 129, 130, 131 i n., B. von Siebert, op., cit., s. 565-567, H. Batowski, Cieśniny.., op. cit., s. 8.

35 ÖUA, t. 4, nr 4252, Mieždunarodnije otnošenija ..., t. 21, cz. 1, nr 147, 179, 180.

36 B. von Siebert, op., cit., s. 562, J. Gozdawa-Gołębiewski, Od wojny krymskiej do bałkańskiej. Działania flot wojennych na morzach i oceanach w latach 1853-1914, Gdańsk 1985, s. 448, przypis 1.

37 J. Gozdawa-Gołębiewski, op. cit., s. 118, Mieždunarodnije otnošenija ..., t. 21, cz. 1, nr 181, 227.

38 B. von Siebert, op., cit., s. 565-567. 
pierwsze posiedzenia konferencji pokojowej. $\mathrm{W}$ ich trakcie okazało się, że reprezentowane przez strony stanowiska są diametralnie różne. Wysunięty przez państwa bałkańskie plan przewidywał odstapienie przez Turcję wszystkich posiadłości europejskich położonych na zachód od linii Rodosto nad Morzem Marmara - Przylądek Malarta nad Morzem Czarnym oraz Krety i innych wysp na Morzu Egejskim ${ }^{39}$, podczas gdy delegacja turecka za wszelką cenę starała się ograniczyć żądania sojuszników do minimum. Stąd też w przedstawionych kontrpropozycjach Wysoka Porta kategorycznie odmówiła oddania wysp na Morzu Egejskim, kwestię przynależności Krety i Albanii sugerowała przekazać do rozpatrzenia konferencji ambasadorów, a godziła się jedynie na oddanie terenów położonych na zachód od Adrianopola, zachowując jednocześnie samą twierdzę $e^{40}$. Takie stanowisko Turcji wynikało przede wszystkim z przeświadczenia, że nadal liczyć może ona na poparcie wielkich mocarstw. Te jednak, w zaistniałej sytuacji ${ }^{41}$, nie zamierzały aktywnie wspierać tureckich koncepcji, a wręcz przeciwnie, starały się przyspieszyć zakończenie obrad konferencji, nawet za cenę większych strat terytorialnych Turcji. Kiedy na skutek uporu negocjujących stron zawisła nad rozmowami groźba ich zerwania, mocarstwa 17. 01. $1913 \mathrm{r}$. zdecydowały się na interwencję ${ }^{42}$, zalecając Turcji zaakceptowanie większości żądań wysuwanych przez państwa bałkańskie. Wymowne sugestie ze strony „koncertu europejskiego" skłoniły Wysoką Portę do ustępstww ${ }^{43}$ i 22.01 .1913 r. rząd turecki wyraził wolę zawarcia pokoju. Spowodowało to jednak tak gwałtowny sprzeciw, że już następnego dnia rząd został obalony w wyniku zamachu stanu ${ }^{44}$. Nowy gabinet, złożony głównie z „młodoturków”, wycofał się ze złożonych przez poprzedni gabinet deklaracji $^{45} \mathrm{i}$ zwlekał z przesłaniem kontrpropozycji ${ }^{46}$. Delegaci państw bałkańskich uznali taką postawę Turcji za pretekst do zerwania rozmów, mimo że wielkie mocarstwa doradzały zachowanie spokoju i oczekiwanie na oficjalne stanowisko rządu tureckie$\mathrm{go}^{47}$. Równocześnie jednak nie zamierzały aktywnie powstrzymywać państw bałkańskich przed wznowieniem działań wojennych.

Tym niemniej kolejne sukcesy sojuszników skłoniły mocarstwa, chcące uchronić Turcję od ostatecznej klęski, do ponownej interwencji. 31.03.1913 r. wręczyły one rządowi tureckiemu notę, w której proponowały pośrednictwo w zamian za zgodę na zaproponowane ustępstwa na rzecz państw bałkańskich. Przewidywały one między innymi: przebieg granicy bułgarsko-tureckiej wzdłuż linii Enos nad Morzem Egejskim

${ }^{39}$ B. von Siebert, op. cit., s. 563 i 564-565, Der diplomatische Schriftwechsel..., t. 3, nr 754, 789, 790,805 .

40 DGP, t. 34, cz. 1, nr 12576, 12577, Mieždunarodnije otnošenija ..., t. 21, cz. 1, nr 115, 204, Der diplomatische Schriftwechsel..., t. 2, nr 544, ÖUA, t. 5, nr 5453, Der diplomatische Schriftwechsel..., t. 3, nr 713.

${ }^{41}$ Za takie uznać należy kwestię albańską i sprawę dostępu Serbii do Morza Adriatyckiego.

42 ÖUA, t. 5, nr 5422, 5423, 5424, 5426.

${ }^{43}$ DGP, t. 34, cz. 1, 12576, 12577, 12578 i n., ÖUA, t. 5, nr 5415, 5417, 5419 i n.

44 ÖUA, t. 5, nr 5509, 5513, 5514, 5536, 5546 i n.

${ }^{45}$ H. Batowski, Państwa..., s. 192.

46 DGP, t. 34, przypis **, s 285, nr 12767, 12772.

${ }^{47}$ Der diplomatische Schriftwechsel..., t. 3, nr 702. 
- Midye nad Morzem Czarnym oraz rozpatrzenie kwestii Albanii i wysp na Morzu Egejskim $^{48}$. Porażona nowymi porażkami Turcja przyjęła proponowane przez mocarstwa warunki, a 1.05.1913 r. wznowiła obrady konferencja pokojowa w Londynie. Pertraktacje znowu jednak przebiegały bardzo wolno i zacięte spory zakończyła dopiero interwencja premiera Wielkiej Brytanii, E. Grey'a. Zdecydowana postawa gabinetu londyńskiego, będąca wyrazem zniecierpliwienia wszystkich mocarstw, skłoniła ostatecznie strony do zawarcia pokoju. Podpisany $30.05 .1913 \mathrm{r}$. $\operatorname{traktat}^{49}{ }^{\text {zobowiazy- }}$ wał Turcję do oddania państwom bałkańskim wszystkich swoich posiadłości europejskich, z wyjątkiem Albanii, położonych na zachód od linii Enos - Midye.

Obrady konferencji w Londynie wskazywały jasno, że w zaistniałej sytuacji Turcja i jej problemy zeszły na dalszy plan w polityce europejskiej. Słabość militarna, Imperium Osmańskiego, która bezlitośnie obnażona została w tracie wojny z Włochami a następnie konfrontacji z państwami bałkańskimi sprawiła, że priorytetem dla wielkich mocarstw stały się ściśle ze sobą związane kwestie - wyznaczenia granic Albanii i serbskiego dostępu do Adriatyku.

Po ogłoszeniu przez Albańczyków niepodległości na Półwyspie Bałkańskim wytworzyła się, bowiem, nowa sytuacja, która zarówno dla Ententy, jak i mocarstw centralnych stwarzała możliwości wzmocnienia swych pozycji w regionie. Stąd też już podczas pierwszej konferencji londyńskiej na przełomie 1912 i 1913 r., w trakcie obrad konferencji ambasadorów, kwestie te zajęły pierwszoplanowe miejsce. Najwięcej kontrowersji budziła sprawa granic przyszłego państwa albańskiego. Ostatecznie wykrystalizowały się trzy koncepcje. Pierwszą reprezentowali sami Albańczycy, którzy postulowali objęcie granicami ich państwa wszystkich 4 wilajetów, tradycyjnie uznawanych za „albańskie”. Jednak żądań tych nie były w stanie przeforsować nawet bardzo przychylnie nastawione do Albańczyków Włochy i Austro-Węgry. Stąd też proponowały one, aby granica nowego państwa bałkańskiego przebiegała wzdłuż dotychczasowej granicy czarnogórsko-tureckiej, obejmując Skutari na północy, następnie biegnąc na południe pozostawić miała po stronie albańskiej $\mathrm{m}$. in.: Prizren, Dibrę i Ochryd oraz objać znaczną część Epiru z Janiną na południu. W opozycji do obu tych koncepcji stała propozycja wysunięta przez sojuszników bałkańskich i popierana przez Rosję. Przewidywała ona, że granice przyszłej Albanii przebiegać powinny od ujścia rzeki Mati, następnie na zachód od Czarnej Driny do Morza Adriatyckiego w okolicach Zatoki Valońskiej ${ }^{50}$, gwarantując tym samym Serbii dostęp do wybrzeża adriatyckiego. Taki stan rzeczy nie był jednak do zaakceptowania dla Włoch, a zwłaszcza Austro-Węgier. W Wiedniu obawiano się, że uzyskanie przez Serbię dostępu do morza wzmocni wpływy rosyjskie w tym rejonie, co stanowić by mogło bezpośrednie zagrożenie dla austro-węgierskiej floty wojennej stacjonującej w Trieście.

${ }^{48}$ E. C. Helmreich, The diplomacy of the Balkan wars, 1912-1913, Cambridge 1938, s. 327, ÖUA, t. $6, \mathrm{nr} 6867$.

49 J. Rubacha, A. Malinowski, A. Giza, Historia Butgarii 1870-1915. Materiaty źródtowe z komentarzami, t. 1, s. 113-115, DGP, t. 34, cz. 2, 13270.

${ }^{50}$ DGP, t. 34 , cz. 1. 
Dlatego też napięcie, jakie towarzyszyło rozstrzyganiu kwestii albańskiej, omal nie doprowadziło do wybuchu konfliktu między Austro-Węgrami a Rosją ${ }^{51}$.

Ostatecznie do realizacji przyjęty został 22.03.1913 r. projekt, wysunięty przez Austro-Węgry, który stworzył państwo albańskie na obszarze dwóch dawnych wilajetów tureckich - szkoderskiego i janinskiego. Cztery miesiące później mocarstwa uchwaliły statut Albanii i uznały ją za niepodległe księstwo pod ich protektoratem ${ }^{52}$. Jakkolwiek decyzja ta wywołała stanowcze protesty Serbii i Czarnogóry, wkrótce zostały one złamane ${ }^{53}$.

Tym samym Turcja znowu zepchnięta została do rangi przedmiotu polityki międzynarodowej, co nie oznaczało, że nie starano się umacniać wpływów w tym kraju, tym bardziej, że wzrost napięcia między mocarstwami, grożący wybuchem ogólnoeuropejskiego konfliktu, motywował je do podejmowania prób zabezpieczania najbardziej newralgicznych regionów. Jednym z nich pozostawały nadal cieśniny czarnomorskie. W wyniku II wojny bałkańskiej granica bułgarsko-turecka została przesunięta dość znacznie na północ w porównaniu z ustaleniami londyńskiego traktatu pokojowego, co niewatpliwie $\mathrm{w}$ pewnym sensie zabezpieczało to newralgiczne miejsce przed ewentualna obcą penetracją. W związku z tym kwestia pozyskania lub wzmocnienia przychylności Turcji stawała się kwestią kluczową. W działaniach na tym polu zdecydowanie więcej inicjatywy wykazały mocarstwa centralne, które wykorzystały niezdecydowanie Ententy oraz niechętny stosunek do niej Wysokiej Porty, zrażonej brakiem wsparcia finansowego w okresie wojny z Włochami. Jesienią 1913 r. w Konstantynopolu pojawiła się niemiecka misja wojskowa pod przewodnictwem gen. Otto Limana von Sandersa, która zająć się miała reorganizacją tureckiej ar$\mathrm{mii}^{54}$. Dzięki temu Niemcy zyskały nie tylko silny wpływ na turecki korpus oficerski, ale przejęły niemal zupełną kontrolę nad kierunkami tureckiej polityki zagranicznej. Tę niebezpieczną sytuację starała się opanować Rosja, ale podjęte przez nią na przełomie 1913 i 1914 r. konsultacje z sojusznikami wykazały ich całkowity brak zainteresowania kwestią statusu cieśnin czarnomorskich ${ }^{55}$. Tym samym wpływy mocarstw centralnych w Turcji nie tylko pozostały nienaruszone, ale uległy dalszemu wzmocnieniu, a Wysoka Porta przystąpiła do I wojny światowej po ich stronie.

${ }^{51}$ M. Tanty, Rosja..., s. 128-131.

52 DGP, t. 34, cz. 2, H. Batowski, Państwa..., s. 198-202, E. C. Helmreich, op. cit., s. 296.

${ }^{53} \mathrm{~W}$ tym celu Włochy i Austro-Węgry 8.05.1913 r. zawarły tajne porozumienie, w którym zobowiązywały się do wspólnej okupacji terytorium albańskiego, która zabezpieczyć je miała przed ewentualną obcą interwencją; Dokumente aus russischen Geheimarchiven..., op. cit., s. 38-41, na ten temat także: Materiali po istorii Franko-russkich..., s. 363, A. Krzyżanowski, op. cit., s. 97-115.

${ }^{54}$ A. Malinowski, op. cit., s. 172.

${ }^{55} \mathrm{BD}$, t. $10, \mathrm{nr} 411$. 


\title{
THE EUROPEAN POWERS POLICY TOWARDS T URKEY IN THE YEARS 1903-1914
}

\author{
JAROSŁAW RUBACHA
}

\section{Summary}

The years 1903-1914 should be considered as the most interesting period in the activity of the great powers states in South-East Europe and Near East for a few reasons discussed below. In the final period of the formation of the antagonistic military-political alliances in Europe, the so called "Concert of Europe" mainly showed a great interest in maintaining the status quo and preventing any conflicts which could occupy their attention. These states also focused on Turkey and especially on its European dominion. As a result, they jointly conducted reforms in Macedonia or tried to prevent the outbreak of war between the High Porte and the Balkan allies in 1912. At the same time, the powers did not stop their endeavors to realize their own political or economic aims at the cost of Turkey (e.g. the annexaion of Bosnia and Hezegovina by Austro-Hungary in 1908, the ocupation of Trypolitania and Cyrenaica by Italy in 1911). Their aim was to eliminate the influences and block the initiative of their competitors (i.a. the British trial to eliminate German economic influences in Turkey after the Young Turk Revlution). Meanwhile, the High Porte, which had at their disposal precious natural resources and a key geopolitical position, appeared as a potential military and strategic ally. In consquence, in 1909 there appeared the plan of joining Turkey to local miliary-politcaly alliances (i.a. the N. Czaykow's mission). The confluence of all these factors and the plans of the Balkan states, which at the time tried to realize their national aims, created a very complicated situation. This situaton precipitaed the outbreak of World War I. 